\title{
Assessment of Technogenic Loading on the Surface Water Bodies of the Separate Regions of the North-Western Black Sea
}

\author{
Angelina Chugai ${ }^{1 *}$, Tamerlan Safranov ${ }^{1}$ \\ 1 Faculty of Nature Protection, Odessa State Environmental University, 15 Lvivska Street, 65106 Odessa, \\ Ukraine. \\ * Corresponding author's e-mail: avchugai@ukr.net
}

\begin{abstract}
The assessment of surface water quality and technogenic loading on the separate regions of the North-Western Black Sea, namely the Mykolaiv region, was performed in this work. The water quality assessment was conducted using the graphical method that allows determining the suitability of water for the certain types of water using, as well as the method of calculating a water pollution combinatorial index. The estimation of the technogenic loading is based on calculating a technogenic loading module. It was found that the surface waters of the Mykolaiv region do not meet the requirements of fisheries in relation to most quality indicators. According to various standards, this surface water quality in this region is characterized by the "polluted" - "very dirty" categories. A reduction of the technogenic loading by the volume of wastewater discharges since 2006 can be determined. According to the pollutant discharge indicators, a steady decrease of the level of loading has been noted since 2005, which is caused by a reduction of wastewater discharges.
\end{abstract}

Keywords: quality assessment, pollutant, wastewater, a technogenic loading module.

\section{INTRODUCTION}

The main reason for the deterioration of the surface water in the regions of Ukraine is their pollution due to the discharge of large quantities of wastewater. That is why, a number of studies are devoted to exploring the effective methods of sewage and surface water treatment from concentrated organic pollution (Malovanyy et al., 2019), heavy metals (Melnyk et al., 2015), ammonia (Malovanyy et al., 2018), petroleum (Zelenko et al., 2019) and biological pollution (Nykyforov V. et al., 2016). This problem is especially acute in the low-water Mykolaiv region. The situation in the region is also greatly complicated by a lack of quality household and industrial wastewater treatment.

The Mykolaiv region is territorially related to the basins of the Southern Bug River, the Dnieper River and the Black Sea rivers. The surface water resources of the region also include lakes, reservoirs, ponds and swamps. The use of artificial water bodies in the region is carried out to meet the needs of energy, drinking water supply, irrigation and household needs (Regional report..., 2019).

The water resources in the region are very limited and depend on the inflows from other regions. According to specific indicators of the water resources (per capita), the region occupies one of the last places among the regions of Ukraine. The Mykolaiv region is the least provided with the explored reserves of drinking quality underground water in Ukraine (Regional report..., 2019).

The largest water consumption in the region is for the production needs, irrigation and drinking, and in the sectors of the economy, i.e. for the energy sector, housing - communal services and agriculture.

Five cities, including Mykolaiv, are supplied with the water from the surface sources of the region. Most rural settlements and district centers use groundwater for drinking purposes. The groundwater extracted in the territory of 
the Mykolaiv region is mainly used to meet the household and drinking needs of the population. This region's groundwater is also used for the balneological purposes (Regional report..., 2019).

The problem of the pollution of the surface water bodies is also acute for the Mykolaiv region. In recent years, there has been a decrease in the volume of inadequately treated wastewater (WW) discharges, which is primarily the result of a decreased production in the region.

It should be noted that the issues of the water quality assessment and technogenic loading on the water bodies of the region have not received much attention in the studies. Thus, the paper (Mitryasova and Selivanov 2014) provided a generalized assessment of the surface water quality in the Mykolaiv region for many years, without providing the details on the content of individual pollutants or water quality indicators, as well as the information about the quality for the relevant period. The research of the authors of this work is interesting with regard to the anthropogenic loading (Baluieva and Chynkuliak 2013). The results of the cluster analysis of the regions of Ukraine by the level of anthropogenic loading, including the volumes of water used and polluted water discharges are presented. Thus, the Mikolaiv region was included in the list of the regions with a low level of loading.

On the basis of the above, the issue of the assessment of the surface water quality and the assessment of technogenic loading on the surface water bodies is urgent for the Mykolaiv region.

\section{MATERIALS AND METHODS}

Two methods were used to assess the surface water quality: the graphical method of the complex surface water quality assessment and the method of the assessment by the hydrochemical parameters.

The graphical method is based on drawing up a graphical model of surface water quality, which is a pie chart with radius scales corresponding to a certain hydrochemical index. The division price of each radius is equal to the maximum value of the indicator concentration, which determines the suitability of water for a certain type of water using, is the maximum permissible concentration $(M P C)$ of pollutants in a water body (Igoshin 2009).
According to the method of the assessment of land surface water quality based on the hydrochemical parameters (a methodology of the Hydrochemical Institute) (Safranov et al., 2015), the water quality is determined through a complex indicator called a combinatorial pollution index $(C P I)$ :

$$
C P I=\sum_{i=1}^{n} S_{i}
$$

where: $S_{i}$ is a total score obtained by multiplying a rate of repeatability of cases of the $M P C$ excess and a rate of multiplicity of the $M P C$ excess.

The limited pollution indicators $(L P I)$ are determined from a total number of ingredients and water quality indicators. The value of a total rating for this ingredient is equal to or greater than 11. There are 4 classes of water quality: weakly polluted, polluted, dirty, very dirty (Safranov T.A. et al., 2015).

In order to estimate the technogenic loading, the principle of calculating a technogenic loading module (TLM), which is defined as a sum of the weight units of all types of (solid, liquid, gaseous) industrial, agricultural and municipal objects waste over a time interval of 1 year, assigned to the administrative region or the area within which these facilities are located, measured in thousand $\mathrm{t} / \mathrm{km}^{2}$ per year, was applied. As it was indicated in the paper (Adamenko and Rudko 1997), the technogenic loading in the overwhelming number of cases is represented by a considerable list of indicators characterizing the impact on the individual components of the environment. On the basis of the principle of TLM determining, the authors offered to estimate the level of technogenic loading on the basis of calculating a module of technogenic loading on the water objects $\left(M_{W O}\right)$, which is defined as a volume of wastewater (or pollutants) discharges into the surface water bodies in thousand $\mathrm{t} / \mathrm{km}^{2}$ per year.

\section{RESULTS AND DISCUSSION}

The data on the average annual concentrations of water quality indicators given in the Ecological passports of the region in 2007-2017 (Ecological passport..., 2008; Ecological passport..., 2013; 
Ecological passport..., 2018) were used to assess the surface water quality. The assessment was carried out for two types of water usage: fisheries and economic-drinking. Figure 1 show the results of the graphical method.

The analysis of the given figures shows that according to the fishery standards, the permanent exceedances of the $M P C$ for the content of such indicators as biochemical oxygen consumption for 5 days $\left(B O C_{5}\right)$, mineralization, chlorides, sulfates, iron, copper, magnesium, phosphates are observed during the period of studies. That is, the surface waters of the Mykolaiv region do not meet the requirements of fisheries for the most quality indicators.

Figure 2 shows the results of calculating the CPI. The analysis of the figure shows that according to the fisheries standards, the value of the indicator is much higher than for the economic and drinking ones. There is a decrease in the value of $C P I$ during the study period. No $L P I$ were detected.

Taking into account the number of water quality indicators used for the assessment in different years, it is possible to make a classification of the surface water quality in the Mykolaiv region according to two types of water using (Table 1). As it can be seen according to the fisheries standards, the surface water quality of the region is characterized by a single class VIa and the "very dirty" category. According to the economic and drinking requirements, the water quality is characterized by classes II - III and the "polluted" - "dirty" categories.

The assessment of the technogenic loading on the Mykolaiv region water objects was made on the basis of the data on the WW discharges/pollutants into the water bodies of the region based

a)
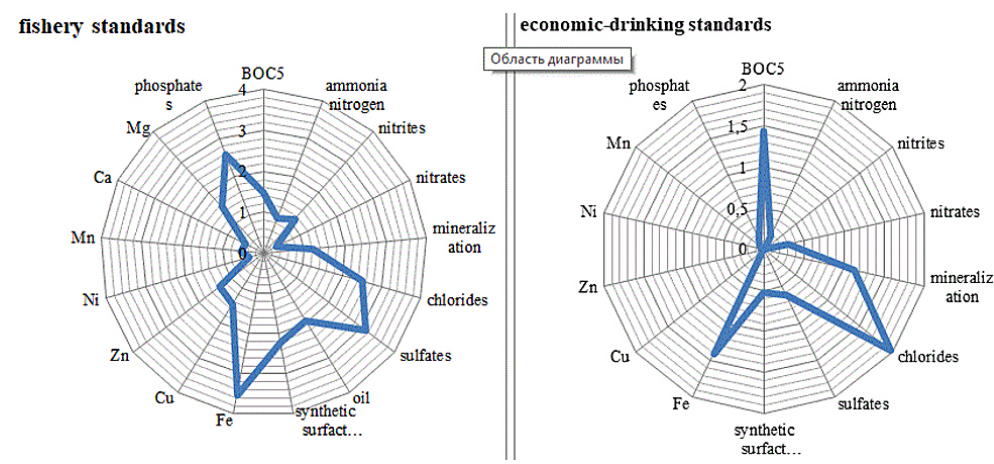

b)
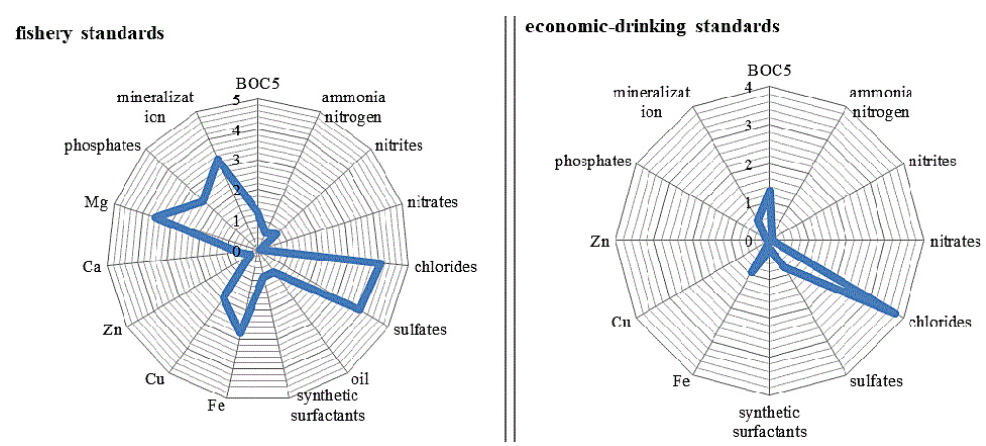

c)
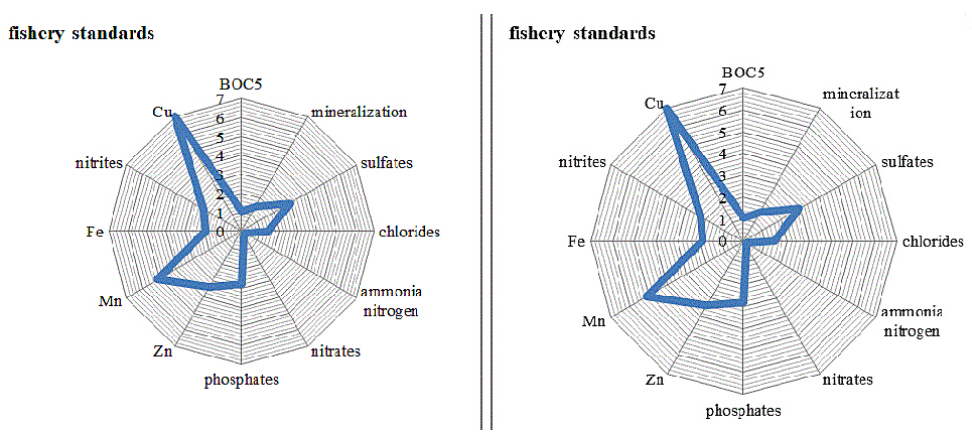

Fig. 1. The results of surface water quality assessment of the Mykolaiv region in 2007 (a), 2012 (b), 2017 (c) 


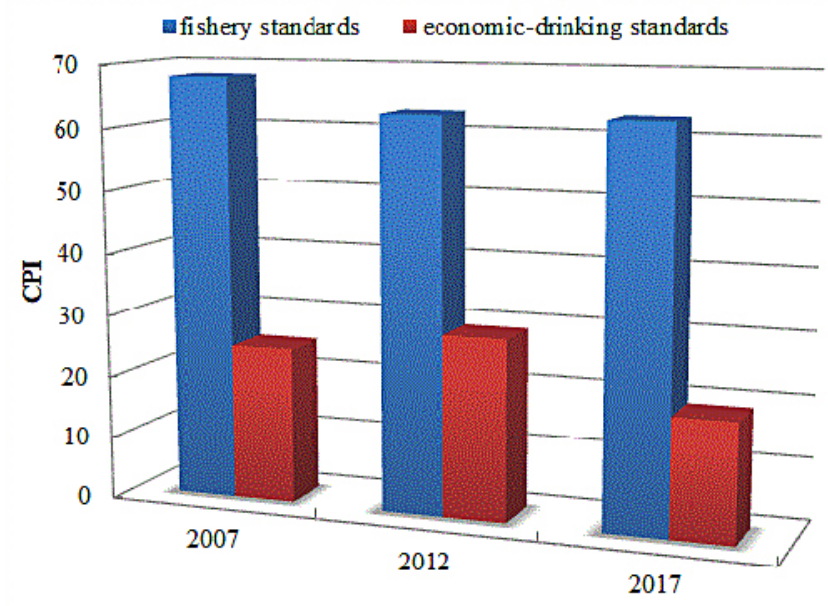

Fig. 2. Dynamics of CPI changing in the surface waters of the Mykolaiv region in 2007-2017

Table 1. Assessment of the surface water quality in the Mykolaiv region

\begin{tabular}{|c|c|c|c|}
\hline Kind of water use & 2007 & 2012 & 2017 \\
\hline Fisheries & Vla, very dirty & Vla, very dirty & Vla, very dirty \\
\hline Economic-drinking & II, polluted & III, dirty & II, polluted \\
\hline
\end{tabular}

a)

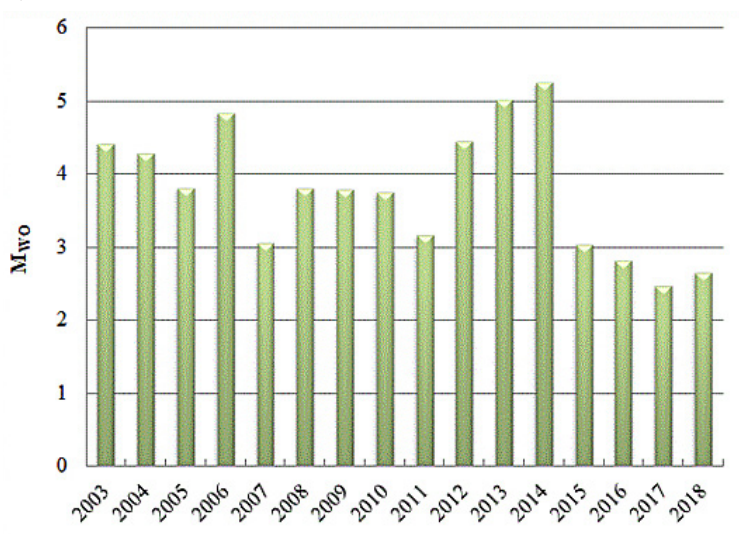

b)

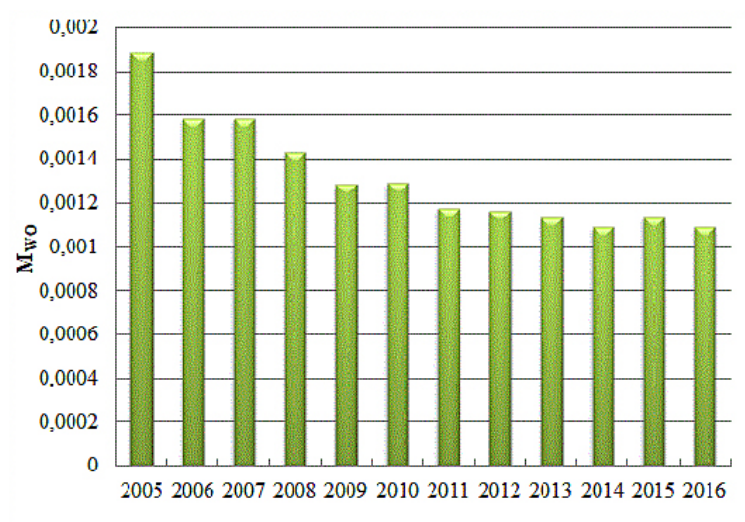

Fig. 3. Dynamics of changing the $M_{W O}$ indicator by the volume of WW discharges in 2003-2018 (a) and of pollutants discharges in 2005-2016 (b) in the Mykolaiv region

on the data given in (Ecological passport..., 2008; Ecological passport..., 2006 ; Ecological passport..., 2011; Ecological passport..., 2014; Ecological passport..., 2017; Ecological passport..., 2019).

Figures 3 show the dynamics of changing the $M_{W O}$ indicator by the volume of WW and pollutant discharges in their composition. It should be noted that due to the lack of data in some years, the technogenic loading assessment was performed for a more limited period of time. The number of pollutants discharges within the wastewaters is 3 orders of magnitude lower. It is not advisable to summarize the $M_{W O}$ indicators by WW and pollutants discharges, but a proposed calculation scheme is necessary to perform a comparative analysis of the technogenic loading on the NorthWestern Black Sea regions in the future.

On the whole, the analysis showed that a level of technogenic loading was varying considerably in the volume of pollutant discharges (Fig. 3a) during the study period. This can be partly explained by the fact that, in some years, the total volume of accumulated water in the regional ponds (20122014) was included in the total volume of WW discharged into water bodies. If these indicators are not taken into account, a gradual decrease in the level of technogenic loading from 2006 to the present time by almost 1.5 times can be noted.

According to the indicators of the pollutant discharges (Fig. 3b), there is a steady decrease in the level of loading almost by 2 times starting 
from 2005. This is due to the decrease of the WW discharges and, accordingly, the pollutants in their composition.

\section{CONCLUSIONS}

On the basis of the calculations, the following conclusions can be drawn:

1. The surface waters of the Mykolaiv region do not meet the requirements of fisheries by most quality indicators.

2. According to the fisheries standards, the surface water quality of the region is characterized by single class VIa and the category "very dirty", according to economic and drinking requirements - classes II - III, the categories "polluted" - "dirty".

3. The number of pollutants discharged into the $\mathrm{WW}$ is 3 orders of magnitude less. In general, the volume of WW discharges shows a gradual decrease of the technogenic loading level from 2006 to the present time by almost 1.5 times.

4. According to the indicators of pollutant discharges, there is a steady decrease in a loading level by almost 2 times since 2005, which is caused by a decrease in wastewater discharges and accordingly the pollutants in their composition.

Thus, it should be noted that the issues of the assessment of surface water quality in the Mykolaiv region, as well as technogenic loading on the water objects are not a priority in the Regional programs and other studies. However, providing the region with quality drinking water is one of the region's main tasks.

\section{REFERENCES}

1. Adamenko O.M., Rudko H.I. 1997. Environmental Geology. Manuskrypt, Kyiv. (in Ukrainian)

2. Baluieva O., Chynkuliak N. 2013. Cluster analyses of the Ukrainian territories according to the indices of the anthropogenic loads on the natural environment. Efektyvna ekonomika, 12. Retrieved from: http:// www.economy.nayka.com.ua/?op $=1 \& z=2574$. (in Ukrainian)

3. Ecological passport of the region for 2005. Mykolaiv region. Mykolaiv 2006. (in Ukrainian)
4. Ecological passport of the region for 2007. Mykolaiv region. Mykolaiv 2008. (in Ukrainian)

5. Ecological passport of the region for 2010. Mykolaiv region. Mykolaiv 2011. (in Ukrainian)

6. Ecological passport of the region for 2012. Mykolaiv region. Mykolaiv 2013. (in Ukrainian)

7. Ecological passport of the region for 2013. Mykolaiv region. Mykolaiv 2014. (in Ukrainian)

8. Ecological passport of the region for 2016. Mykolaiv region. Mykolaiv 2017. (in Ukrainian)

9. Ecological passport of the Mykolaiv region for 2017. Mykolaiv 2018. (in Ukrainian)

10. Ecological passport of the region for 2018. Mykolaiv region. Mykolaiv 2019. (in Ukrainian)

11. Igoshin N.I. 2009. Problems of restoration of small rivers and reservoirs. Hydroecological Aspects: A Training Manual. Burun Book, Kharkov. (in Russian)

12. Malovanyy M. et al. 2018. Two stage treatment of solid waste leachates in aerated lagoons and at municipal wastewater treatment plants. Eastern-European Journal of Enterprise Technologies, 1 (10), 23-30. doi.org/10.15587/1729-4061.2018.122425.

13. Malovanyy M. et al. 2019. Perspective technologies of the treatment of the wastewaters with high content of organic pollutants and ammoniacal nitrogen. Journal of Ecological Engineering, 20(2), 8-15. https://doi.org/10.12911/22998993/94917.

14. Melnyk L. et al. 2015. Adsorption of heavy metals ions from liquid media by palygorskite. Chemistry \& Chemical Technology, 9(4), 467-470. https://doi. org/10.23939/chcht09.04.467.

15. Mitryasova O.P., Selivanova A.M. 2014. Evaluation of the ecological status of surface water resources of the Mykolaiv region. Scientific papers of the Black Sea State University named after Peter Mohyla of the Kyiv Mohyla Academy Complex. Series: Ecology. 232, 220, 92-96. (in Ukrainian)

16. Nykyforov V. et al. 2016. The biotechnological ways of blue-green algae complex processing. Eastern-European Journal of Enterprise Technologies, 5(10), 11-18. https://doi.org/10.15587/17294061.2016.79789.

17. Regional report on the state of the environment in Mykolaiv region in 2018. 2019. Mykolaiv. (in Ukrainian)

18. Safranov T.A. et al. 2015. Systematic analysis of environmental quality. Textbook. Ecology, Odessa. (in Ukrainian)

19. Zelenko Y. et al. 2019. Optimization of heat-andpower plants water purification. Chemistry \& Chemical Technology, 13(2), 218-223. https://doi. org/10.23939/chcht13.02.218 